\title{
COVID-19 TOURISM IMPACTS IN SOUTH AFRICA: GOVERNMENT AND INDUSTRY RESPONSES
}

\author{
Christian M. ROGERSON" \\ University of Johannesburg, School of Tourism and Hospitality, South Africa, e-mail: chrismr@uj.ac.za \\ Jayne M. ROGERSON \\ University of Johannesburg, School of Tourism and Hospitality, South Africa, e-mail: jayner@uj.ac.za
}

\begin{abstract}
Citation: Rogerson, C.M., \& Rogerson, J.M. (2020). COVID-19 TOURISM IMPACTS IN SOUTH AFRICA: GOVERNMENT AND INDUSTRY RESPONSES. GeoJournal of Tourism and Geosites, 31(3), 1083-1091. https://doi.org/10.30892/gtg.31321-544
\end{abstract}

\begin{abstract}
The COVID-19 pandemic is having devastating economic and social consequences in the global South. This article is a rapid response critical assessment and examines COVID-19's emerging impacts for the tourism sector of South Africa, one of the world's worst affected destinations. Specific focus is upon responses by industry and government to the crisis and its unfolding impact for the tourism sector. The study is situated within the context of an expanding tourism scholarship and debates around the pandemic. Findings show a hollowing out of the South African tourism industry is taking place at an accelerating tempo with the most severely impacted being tourism small and micro-enterprises. The study highlights the occurrence of conflicts between key stakeholders and especially the frustrations of the tourism industry about the chaotic and changing policy regulations towards the sector as well as the weakness of government support interventions.
\end{abstract}

Key words: COVID-19; South Africa; lockdown; government and industry responses

\section{INTRODUCTION}

On 1 August 2020 South Africa's Minister of Health made the grim announcement that more than half a million cases of coronavirus had been confirmed in the country. This tally meant that South Africa was by far the most hard-hit country in Africa accounting for half of all reported infections for the continent. Globally, South Africa was now ranked as the fifth worst affected country following the USA, Brazil, Russia and India. The first recorded case was reported on 5 March, an imported infection by a 38 year old man who had travelled back to South Africa from Italy. Only a week later the country was reporting its initial cases of community transmission which triggered the declaration of a National State of Disaster by President Cyril Ramaphosa on 15 March 2020. Twelve days later with 1170 confirmed cases and one recorded death South Africa was placed under strict lockdown (Rogan and Skinner, 2020). The Western Cape province with Cape Town its major city was the region of South Africa earliest impacted by the virus. Inevitably a spatial diffusion of the virus took hold and by July 2020 the epicentre of COVID-19 infections had shifted geographically to Gauteng, South Africa's economic heartland centred around the cities of Johannesburg and Pretoria.

The Ministerial announcement about the milestone of more than 500000 recorded COVID cases came two weeks after the release of the findings of the National Income Dynamics Study (NIDS) Coronovirus Rapid Mobile Survey (CRAM) which was the result of cooperative research undertaken by a consortium of 30 social scientists drawn from five different South African universities (Spaull et al., 2020). The survey reported the findings of a broadly representative sample of 7000 respondents which interrogated aspects of their employment and welfare in the wake of the unfolding COVID-19 pandemic. The NIDS-CRAM study provides a 'barometer' to assess how firms and families have been impacted by the pandemic and the severe lockdown that was imposed by national government (Spaull et al., 2020). The key results pertain to the period of February to April 2020, an especially difficult time in ter ms of the lockdown regime in South Africa. They portray clearly the economic and social devastation that can be wrought by the pandemic in the environment of the global South. The results are highly significant when set in the broader context of sub-Saharan Africa as the World Health Organisation views the South African experience as a precursor to what might transpire in the rest of the continent. The study revealed an 18 percent decline in employment across the period February to April 2020 with the shedding of 3 million jobs (Jain et al., 2020; Ranchhod and Daniels, 2020). Most important is that these employment losses were disproportionately concentrated among the already disadva ntaged in the labour market such as women, manual workers and individuals in lower-income households (Casale and Posel, 2020). The South African record was that adverse effects were disproportionately impacting those groups who always have been vulnerable such as women as a whole, Blacks, youth and the less educated groups (Casale and Posel, 2020; Köhler and Bhorat, 2020). Above all those workers in the informal economy were hit the hardest as a larger proportion of informal economy workers were literally "locked out of employment" as compared to those in formal work (Rogan and Skinner, 2020). Before COVID-19 South Africa was already one of the most unequal societies in the world notwithstanding certain achievements secured since democratic transition in 1994 (World Bank, 2018). This said, some of the progress of the early post-apartheid years in reducing inequalities was undermined during the disastrous Presidency of Jacob Zuma from 2009 to 2018 when corruption became endemic and the economy stagnant. The immediate impress of COVID-19 in South Africa has been to exacerbate significantly the existing stark inequalities along the traditional lines of race, gender, occupation, earnings and location (Spaull et al., 2020). An unequal national situation in terms of economic and social inequality thus has been made far worse as a consequence of the COVID-19 pandemic (Spaull et al., 2020).

It must be appreciated that the NIDS-CRAM investigation is cross-sectoral in character and does not afford specific insight into the impacts for the tourism sector of South Africa. Research by the OECD (2020) points to the projection that the socio-economic implications of COVID-19 in Africa will be experienced most severely by those countries in which tourism is a leading economic sector. Since 1994 with South Africa's re-insertion into the global economy the country's tourism sector has experienced considerable expansion; by 2018 the country was welcoming 10 million international visitors ranking it as one of Africa's leading tourism destinations (Rogerson and Rogerson, 2018). It is against this background the objective in this paper is to examine the emerging impacts of COVID-

\footnotetext{
Corresponding author
} 
19 upon the country's tourism sector and of the responses undertaken by government and the industry. An analysis of the role of industry and government is vital for understanding the impacts of COVID-19 within particular countries as well as relevant for moving towards recovery efforts (Assaf and Scuderi, 2020; Thomas and Laesser, 2020). Two major sections of discussion follow. As context the next section gives an overview of emerging directions and debates in the burgeoning international tourism scholarship about COVID-19. Attention then shifts to South Africa and an assessment of the unfolding responses of government and the tourism industry to the pandemic. Methodologically, this paper follows that of a number of parallel investigations which have appeared recently as a 'rapid response' critical assessment that brings together a variety of available sources and intelligence on COVID-19 impacts (Baum et al., 2020; Bogale et al., 2020; Foo et al., 2020; Gössling et al., 2020; Korinth and Ranasinghe, 2020). The research is anchored on the triangulation of media reports, policy documents and initial evaluative surveys conducted of the pandemic's impact on firms.

\section{EMERGING DIRECTIONS OF TOURISM SCHOLARSHIP CONCERNING COVID-19 IMPACTS}

It has long been recognised that tourism is a highly vulnerable sector to disruption by hazard events with localized phenomen on such as earthquakes, bushfires, volcanic explosions, tsunamis or floods as well as global events such as disease pandemics (Laws et al., 2007; Ritchie, 2009; Hall, 2010; Butler, 2017; Lenggogeni et al., 2019; Ritchie and Jang, 2019). The appearance of the COVID-19 pandemic, however, constitutes an exceptional shock event posing tourism's greatest challenge since the 2008 global financial crisis. For some scholars it is arguably precipitating "the most profound economic downturn since the Great Depression" (Cheer, 2020: 514). Zenker and Kock (2020: 2) contend the COVID-19 pandemic is unique in scale and constitutes "a combination of a natural disaster, a socio-political crisis, an economic crisis and a tourism demand crisis". The outbreak of the COVID-19 pandemic has been labelled as a "black-swan event' and even likened to scenes reminiscent of World War Two as it precipitates turmoil across the world economy with adverse implications across nearly all sectors of activity and social existence (Hamidah et al., 2020; Nicola et al., 2020). Indeed, the 2020 COVID-19 pandemic is "the third and greatest economic, financial and social shock of the 21 st century after 9/11 and the global financial crisis of 2008" (OECD, 2020: 3). Beyond the pandemic's economic implications are its mounting social implications in respect of tourism (Butcher, 2020; Huijbens, 2020; Qiu et al., 2020).

At its core the tourism sector is reliant on mobility and sociability, the two things that COVID-19 has undermined. Indeed, as Butcher (2020: 27) observes "social distancing diminishes the pleasure of a holiday to the extent that many may choose to stay home". Accordingly, the tourism sector, including commercial aviation, has experienced amongst the worst socio-economic ramifications of the pandemic (Butcher, 2020; Dube et al., 2020; Gursoy and Chi, 2020; ILO, 2020; OECD, 2020; UNCTAD, 2020). Assaf and Scuderi (2020: 731) observe that for tourism COVID-19 "has been one of the most impactful and tragic pandemics of modern times". Within a period of only a few months "the framing of the global tourism system moved from overtourism to "non-tourism"" (Corbisiero and La Rocca, 2020: 95). It is no exaggeration to suggest that "we are in an era of major change of the equivalent of a world war or great depression" (Higgins-Desbiolles, 2020a: 620). Because of the pandemic the world's economy closed down almost overnight resulting in unprecedented challenges for tourism and hospitality enterprises (Dube et al., 2020; Gursoy and Chi, 2020). During July 2020 the World Health Organisation announced that the COVID-19 was 'easily' the most severe global health emergency it has ever declared. By the close of July 2020 the number of recorded cases globally had reached 17, 514611 with a total of (at least) 677591 deaths. Coronavirus is destroying national and local economies triggering the worst economic and humanitarian crisis since the Second World War. Pointing to current estimates that 75 million jobs in the global tourism industry are at immediate risk Zenker and Kock (2020: 1) consider the COVID-19 pandemic as "one of the most impactful events of the $21^{\text {st }}$ century". As the business of tourism is contingent upon the bringing together in close contact of groups of people from different - sometimes far away - locations it is unsurprising that tourism as well as sports events, festivals and attractions were among the first businesses to be closed and subsequently placed under lockdown situations (Thomas and Laesser, 2020). The effective shutdown of international and domestic tourism is seen "as unfortunate casualties of the crisis" (Higgins-Desbiolles, 2020a: 611).

Higgins-Desbiolles (2020a: 611) maintains that the pandemic represents "a watershed moment" in the history of tourism. Likewise, Bianchi (2020: 80) acknowledges that COVID-19 is a "major turning point for global tourism". In addition, it has not only underlined the magnitude and scope of tourism's global importance but also highlighted "the manner in which the interconnected global architecture of tourism and associated flows of mobility act as a vector for the transmission of such pathogens" (Bianchi, 2020: 80). Among others both Novelli (2020) and Smith (2020) highlight that only weeks before the global shutdown tourism scholars were engaged in critical debates around tourism de-growth, chronic overtourism and of campaigns for customers to go on 'flight diets' to address the climate crisis. The COVID-19 induced lockdowns, stay-at-home orders and border restrictions paralyzed tourism and radically shifted the narrative instead to focus upon the impacts of undertourism which now threatens millions of livelihoods (Russo, 2020). As emphasized by Gössling et al. (2020) the worldwide spread of the pandemic is not only causing a global crisis for hospitality and tourism but also dramatically changing consumers' wants and market demands that were satisfied by existing tourism value chains and business models during the pre-COVID-19 era.

Calls have been sounded for forging a "new relationship between tourism and capitalism" as a result of COVID-19 (Cave and Dredge, 2020: 503). Arguably, pre-COVID the tourism industry functioned "largely under a free-market capitalism which worked such as to hollow out society, privatise public goods and services and ceded extensive power to the corporate sector" (Higgins-Desboilles 2020b: 66). Sigala (2020: 3) considers COVID-19 as a crisis of "economized societies rooted in the growth paradigm". A host of leading international tourism scholars currently view the pandemic as a transformative opportunity for the tourism sector as well as for a resetting of tourism research agendas (Bianchi, 2020; Brouder, 2020; Carr, 2020; Cheer, 2020; Gössling et al., 2020; Gretzel et al., 2020; Hall et al., 2020; Higgins-Desbiolles, 2020a, 2020b; Lew et al., 2020; Niewiadomski, 2020; Rogerson and Baum, 2020; Sigala, 2020).

For example, pointing out that the neoliberal version of globalization is associated with environmental devastation, economic inequality and excessive global travel, Goffman (2020: 48) maintains that the "pandemic provides opportunities for a new kind of glocalization in which people live far more local lives than in recent decades but with greater global awareness". Tomassini and Carvagnaro (2020) maintain that the COVID-19 global crisis forces people to re-think the space both inside and outside of tourism by refocusing on the local dimension of our space as the only guarantor of safety and security. Lapointe (2020) asserts therefore that one apparent shift is of a relinking of tourism to host communities as part of a survival strategy at a time when there are no tourists. Similar sentiments are expressed by Romagosa (2020) who identifies opportunities for sustainable and 'proximity' tourism.

The vision for some observers is that the tourism sector be reoriented and should sit within a sound economy and society that is geared towards social and ecological well-being (Higgins-Desbiolles, 2020a; Ioannides and Gyamóthi, 2020). Carr (2020: 30) avers that the COVID-19 pandemic represents "an opportunity to re-envision our economies, possibly accelerating governments' responses to environmental practices that have negatively impacted nature". Further Sigala (2020: 1) views the unprecedented circumstances and ramifications of COVID-19 "demonstrate signs that this crisis is not only different, but it can have profound and long-term structural and 
transformational changes to tourism as a socio-economic activity and industry". Certain observers consider that the crisis might be a catalyst for the affirmation of more sustainable alternatives which align more closely with the United Nations Sustainable Development Goals (Bianchi, 2020; Brouder et al., 2020; Higgins-Desbiolles, 2020b). For Prayag (2020) COVID-19 is the time for a reset not only for the tourism industry but also for the priorities of tourism researchers.

Arguably, it is certain that in terms of mobility restrictions imposed in relation to coronavirus, international travel will be the last to be reactivated. For most countries it will be linked to the appearance of a vaccine and its mass availability (Hall et al., 2020). Tourism as we have known it in the pre-COVID-19 years will be a thing of the past and maybe even a research focus only for curious historical tourism scholars (Tourism Research Network, 2020). Nevertheless, it is inevitable that some form of touris $m$ will re-emerge, albeit different in character to the 'normal' of the pre-COVID-19 tourism economy. As an example, grounded business travellers are beginning to concede that virtual business meetings and even virtual conferences can be held on a satisfact ory basis. Conferences as events may therefore be reduced in significance. Richards and Morrill (2020) emphasize that the youth travel sector faces considerable challenges in adapting to the 'new normal' and will have to re-model existing backpacker hostels in order to meet requirements for social distancing.

In re-imagining a post-viral tourism world, solutions and pathways to recovery inevitably will vary sector-by-sector and destinationto-destination. Prideaux et al. (2020) consider that in the short-term the post-COVID-19 recovery of tourism will be tied to the pace of global economic recovery. However, long-term recovery "will overlap with the transformation of the current linear economic production system into a carbon-neutral economic production system and set new parameters for the future direction of global tourism recovery" (Prideaux et al., 2020: 668). Most commentators are of the opinion that destination recovery must begin with domestic markets and followed by regional tourism markets (Gössling et al., 2020). Other tourism researchers identify the importance of visiting friends and relatives (VFR) travel as a critical element for tourism recovery strategies (Backer and Ritchie, 2017; Rogerson and Baum, 2020). Overall, the assurance of the safety of tourists is stressed as of paramount significance for re-activating tourism as shown by recent investigations of visitor intention to travel (Turnšek et al., 2020).

\section{COVID-19 AND SOUTH AFRICA}

In South Africa, as elsewhere in the world, the country's tourism sector in 2020 has been devastated by the novel coronavirus pandemic. The ramifications for tourism were evidenced immediately following the declaration of a National State of Disaster and the President's announcement made on 15 March 2020 of a three-week hard lockdown period for the country which was extended subsequently to 30 April 2020. As stressed by Rogan and Skinner (2020: 5) in an international comparative perspective South Africa's lockdown regulations were harsh as "all citizens were instructed not to leave their homes other than to access food, medicine, and social grants, and only workers defined as 'essential service' providers could travel". Over 70000 military personnel along with the police force were deployed by the state to enforce these restrictions. Further, in the international context, one of the most distinctive aspects of the hard lockdown imposed in South Africa was the prohibition of sales of alcohol, a ban which was in force from 27 March until 1 June 2020. This section is organised around three themes, namely: (1) an overview of pandemic responses initially made by government and industry; (2) a discussion of national strategy, tourism support measures and recovery planning for tourism; and, (3) evidence of emerging impacts for tourism enterprises.

\section{Initial responses: Government and industry}

Immediately following upon the National State of Disaster declaration a range of responses occurred from some of the country's most iconic attractions. The Table Mountain Cableway, Two Oceans Aquarium and the Zeitz Mocca Art Gallery in Cape Town instituted a complete closure until after Easter; other attractions such as Kirstenbosch Gardens (Cape Town) and Pretoria Zoo decided to stay open but with extra hygiene measures put in place. The announcement of the introduction of a national lockdown beginning on 26 March once more radically changed the business horizon for tourism (Joubert, 2020). On 27 March 2020, the day following the commencement of lockdown, South African Tourism - the national tourism promotion agency - released an emotional video with the message "Don't Travel Now So you can Travel Later". As the tourism sector of South Africa was not classified as "an essential service" it was required to adhere to the stringent national lockdown regulations (Rogan and Skinner, 2020). As has occurred in many countries, small tourism businesses in South Africa overnight went from being relatively stable operations to instead facing potential bankruptcy with retrenchment of workers and negotiated pay-cuts for others (Joubert, 2020). SANParks, the guardian agency of some of the country's most iconic attractions including Kruger National Park, shutdown all facilities across its network of national parks. For South Africa's vital private game lodge sector the COVID-19 lockdown had catastrophic consequences with cancelled bookings and closure of safari lodges (Smith, 2020a). Immediate and devastating effects correspondingly are imposed for local communities that rely on the economic health of such businesses. Vulnerable communities situated in remote areas around lodges were disadvantaged further by the suspension of many community development outreach projects, including many for producing fresh food or craft goods for sale at the lodges. Less than a month after the declaration of the national state of disaster SANParks was leading an initiative for the distribution of food parcels to vulnerable rural communities bordering the Kruger National Park that had been reliant upon tourism for jobs and livelihoods (Mitchley, 2020).

The first consequences for the country's urban accommodation services sector were that nearly all establishments were compelled to shut business operations and expected to remain closed potentially for several months (Anderson, 2020). During March 2020 Tsogo Sun, one of South Africa's largest hospitality groups, announced that the unprecedented step to "deactivate" or temporarily close its 36 hotel properties across the country. In a similar reaction to lockdown Sun International moved to close all its hotels and casino-resorts in South Africa including its luxury hotels at Sandton, Johannesburg and at the Victoria and Alfred (V \& A) Waterfront, Cape Town. Only a handful of hotels across South Africa remained open once lockdown commenced. Essentially these were hotels servicing existing guests, overseas visitors waiting for flights to their home country or providing rooms for 'essential service workers' many stationed at nearby hospitals (Anderson, 2020; Smith, 2020b). The five star Radisson Blu, adjacent to Cape Town's V \& A Waterfront, was identified during initial planning for the pandemic as one hotel to accommodate those remaining international travellers during the nationwide lockdown (Thompson, 2020). The hotel implemented strict health and safety measures as recommended by the World Health Organisation (Thompson, 2020).

Under the COVID-19 Block Exemption for the Hotel Industry the hotel industry was allowed also to engage with the Department of Tourism and Department of Health to make available empty hotels for use as quarantine locations (Republic of South Africa, 2020a). The first such development occurred in March 2020 when South African citizens arriving back from Wuhan, China were quarantined in isolation at The Ranch Hotel, $25 \mathrm{~km}$ from Polokwane, Limpopo. Several potential sites had been under investigation for such a quarantine facility (Ngqakamba, 2020). These included a lodge in KwaZulu-Natal, an open veld site close to Upington in Northern Cape and at Thaba Nchu in Free State close to the Lesotho border. The KwaZulu-Natal lodge was rejected on the grounds of insufficient rooms and travel time from the airport. The Upington site required tents and was not ideal for a large group. For Thaba Nchu, whilst there were concerns about the number of rooms as well as whether the 
nearest airport had adequate landing space, the critical grounds for rejection were that its owners attempted "to drastically increase its original price for the use of the facility" (Karrim and Cowan, 2020). The final choice of the Ranch Hotel was influenced by the fact that it was situated on a major freeway and that there were no communities in close proximity, that all entrances to the area could be secured and that the venue needed to be comfortable as the evacuees from China were not sick so could relax whilst under observation (Ngqakamba, 2020).

In a parallel with European experiences (cf. Thomas and Laesser, 2020) a number of private sector initiatives were launched in South Africa from a recognition that their lodging properties have additional functionalities than simply tourist services. An interesting example of hotel use as quarantine location is Newlands Park Inn in Cape Town, the managers of which recognised the need for flexibility, and so volunteered its use as quarantine for the repatriation of people who had been working at sea such as those persons engaged in marine research (Gibbings, 2020). The City Lodge Hotel group offered its hotel properties to the Department of Health as quarantine locations to accommodate returning South Africans from overseas who had to undergo a 14 day mandatory quarantine in a facility location determined by government. Another quarantine initiative was that by Capital Hotels and Apartments, an operator of a network of self-serviced apartments, all of which are situated in prestige upmarket locations in South Africa's major cities - in Johannesburg at Sandton, Melrose and Rosebank, in Pretoria at Menlyn, in Durban at Umhlanga and in Cape Town close to the city's iconic tourist attraction of the Victoria and Alfred Waterfront development. Following the announcement of the national state of disaster it was reported that occupancy levels in the group's nine hotels had dropped from 80 percent to 10 percent. Instead of closing facilities, the Capital Group - in similar fashion to City Lodge - approached the Department of Health with a proposal to accommodate initially those travellers from countries who had to remain in isolation for 14 days. With the almost complete cessation of international flights and of evacuation flights of South Africans stranded overseas the group shifted its focus instead to a partnership with Discovery Health, South Africa's leading private sector health provider, to offer now a network of sanitised 'isolation hotels' (Discovery Health, 2020). This arrangement offers an alternative to home-based isolation for individuals either diagnosed with COVID-19 but with only mild illness or for those awaiting test results. The facilities are marketed as a safe place for private sector patients to isolate away from their families. Approval was also given by the state for Capital Group properties to offer rooms for work purposes. In other words, individuals would be 'working from home' by staying in one of the Capital Group Hotels. It was reported in May 2020 that the company's strategy for repositioning had achieved 80 percent occupancy levels at its Johannesburg and Pretoria hotels albeit at only one-third of its budgeted revenue because of discounted rates (Anderson, 2020).

National government and provincial governments across South Africa engaged in a search for appropriate quarantine locations for use by the public health sector in each of the country's eight metropolitan areas and 44 district municipalities. In Gauteng these included exhibition centres and in Western Cape the use of remote mountain resorts as well as spa resort facilities. In Eastern Cape province, however, the selection of quarantine locations has been impacted by factors of political patronage. Illustratively, at Cala in the Emalahleni local municipality (part of Chris Hani District Municipality) one lodge owned by the daughter of a senior politician in the provincial government was 'approved' for use by infected COVID patients. For several days before their eventual removal to local hospitals these patients were accommodated at the lodge at considerable public expense and correspondingly with major financial benefits for the lodge owners (Jacob, 2020). Further controversy over choice of quarantine locations arose in Mpumalanga. Here the government-owned Zithabiseni Resort \& Conference Centre at Groblersdal was used to accommodate quarantined South Africans who had been repatriated from Mozambique. Like many provincial government-owned tourist facilities in the province, including resorts and caravan parks, the resort had been rundown as a result of neglect of basic maintenance. In May 2020 quarantined people at the resort threatened to take the Mpumalanga government to court in the wake of multiple complaints about appalling living conditions which were detailed as "unbearable and unhygienic" (Yende, 2020).

\section{Strategy, tourism support measures and recovery planning}

South Africa's long-term planning response to the COVID crisis for the phased withdrawal of lockdown measures was announced on 23 April 2020 and was based upon a report prepared for The Presidency (2020). At its core is a governance framework for a 'risk-adjusted strategy' for economic activity which is based upon different levels of alert and adapted to the epidemiological threats associated with the COVID outbreak (Table 1).

Table 1. Levels of Alert in South Africa's Risk-Adjusted Strategy for Phasing-out Lockdown (Source: Authors note - TBA: to be announced)

\begin{tabular}{|c|l|l|l|}
\hline Alert Level & \multicolumn{1}{|c|}{ Defining Features } & \multicolumn{1}{|c|}{ Implementation Period 2020 } & \multicolumn{1}{|c|}{ Measures } \\
\hline Level 5 & High virus spread and/or low health system readiness. & $\begin{array}{l}\text { March originally for three } \\
\text { weeks but extended to 30 April }\end{array}$ & Full lockdown \\
\hline Level 4 & Moderate to high virus spread with low to moderate health system readiness & 30 April to 30 May \\
\hline Level 3 & Moderate virus spread, with moderate health system readiness & 31 May - ongoing \\
\hline Level 2 & Moderate virus spread with high health system readiness & TBA & Moderate restrictions \\
\hline Level 1 & Low virus spread with high health system readiness. & TBA & TBA \\
\hline
\end{tabular}

At the outset of policy development an assessment was conducted of the risks of transmission and potential for mitigation across all different sectors of the South African economy. Nine criteria were evaluated, viz., proportion of employees that could work remotely, share of workforce aged over 50 years, share of workforce in areas with highest transmission (metropolitan areas), ability to enforce social distancing in the workplace, capacity to screen all employees and to isolate those ill, proportion of employees who utilise public transport, and share of workforce that needed to cross a provincial boundary. The hotel, restaurant and tourism sector was viewed as that which posed the highest risk; by contrast, the lowest risk levels were for finance and the automotive sector. The risk-adjusted strategy proposed a single national alert level but opened the possibility of a geographically differentiated approach for each of the country's nine provinces (The Presidency, 2020). It was suggested that with the highest rate of COVID infections occurring in metropolitan areas provincial premiers might determine an alert level for specific districts within each province allowing those districts with lower risk levels to open up more economic activities. During mid-May national government stated it was shifting away from a 'one-size-fits-all' strategy in terms of its approach for opening-up the economy. The Minister of Health announced different levels of alert might be applied on a district-based approach and with the allocated level dependent on infection rates; COVID hotspots would remain at a higher level of lockdown restrictions than areas with small numbers of cases (Karrim, 2020). By July, however, the Trade and Industry Policy Secretariat (TIPS) was reporting there was taking place a "sharp readjustment of the national strategy on the pandemic" (TIPS, 2020: 7). The suggested policy approach of districtlevel restrictions on hotspots was jettisoned as it became clear "government and especially its scientific advisors want to avoid renewed restrictions on economic activities, however risky" (TIPS, 2020). The major exceptions, however, were the continued ban on the sale of cigarettes and the re-imposition of the alcohol ban (which had been relaxed on 1 June as part of level 3) on 12 July 2020 . The prohibition 
on alcohol sales was rationalised by government Ministers on the grounds of building or retaining capacity in the health sect or. As a whole TIPS (2020) expressed the concern that in managing economic policies around the pandemic government relied overly on advice from epidemiologists and other medical scientists rather than economists and social scientists. This said, one of the South A frican government's leading advisors, a medical scientist, lambasted the lockdown and that evidence for certain of its regulations as "uncompelling". It was declared: "This (lockdown) strategy is not based in science and is completely unmeasured almost as if someone is sucking regulations out of their thumb and implementing rubbish" (cited in Karrim and Evans, 2020).

In common with responses made by governments in many countries (Laesser, 2020) in South Africa a suite of relief measures to cushion the worst effects of the COVID-19 crisis were introduced. One specific support intervention for tourism launched by national government in South Africa was a controversial R200 million Tourism Relief Fund which was declared as aligned with its vision to ensure 'sustainable' and 'inclusive' development (Department of Tourism, 2020; Republic of South Africa, 2020b). The fund offers support to successful applicants - only 4000 in total - of a small grant which was capped at R50 000 (1 August 2020 Exchange rate 1 US\$ = R17.43). Eligibility is indicated to include all forms of accommodation establishments, hospitality and related services, and travel and related services (Department of Tourism, 2020). Nevertheless, as the Tourism Relief Fund is administered in line with government's objectives of economic transformation and is to be guided by the Tourism Broad-based Black Economic Empowerment (B-BBEE) Codes of Good Practice it is in practice therefore geared to support (mainly if not exclusively) survivalist (Black-owned) tourism small, medium or microenterprises (SMMEs). In order to receive aid businesses "would have to prove they are in distress because of COVID-19" (Cronje, 2020).

The fine print details of the distribution criteria for this fund make clear that it is aligned directly with government's empowerment programmes for transformation in the racial complexion of ownership and beneficiaries of the South African tourism sector (Abrahams, 2019). It was stated that the "relief will be distributed in a spatially equitable manner to ensure all provinces benefit"; in terms of allocation "at least 70 percent of beneficiaries will be businesses that are Black-owned", "at least 50 percent of beneficiaries will be businesses that are women owned", "at least 30 percent of beneficiaries will be businesses that are youth-owned" and "at least 4 percent of beneficiaries will be businesses that are owned by people with disabilities" (Kubayi-Ngubane, 2020a). Accusations were dismissed in a High Court case that the criteria for dispensing relief funding were 'racist' as they would exclude applications from 'minority' (whiteowned) businesses. The Court accepted the view of the Department of Tourism that with limited funds available that it had to prioritise applicants from previously disadvantaged communities (Khumalo, 2020). The desperate plight of most SMMEs (the majority of which are white-owned enterprises) in the South African tourism sector was evidenced by reports that one month after issuing the call for support, the Fund was overwhelmed by the numbers of applications coming variously from tour guides, restaurants, travel agencies and owners of bed and breakfast establishments. The Ministry of Tourism conceded "the nature of SMMEs is such that the dearth of business activities for more than a month, could spell the end for such businesses" (Republic of South Africa, 2020b).

Table 2. Directions of Planning for South Africa's Tourism Recovery Plan (Source: Authors based on draft presentations by South African Tourism)

\begin{tabular}{|c|c|}
\hline $\begin{array}{c}\text { Strategic } \\
\text { Thrust }\end{array}$ & Recommendations \\
\hline $\begin{array}{l}\text { 1. Protect and } \\
\text { Rejuvenate } \\
\text { Supply }\end{array}$ & $\begin{array}{l}\text { - Conclude a comprehensive industry/government recovery partnership to collaborate on all aspects of tourism recovery. } \\
\text { - Deploy an enhanced Tourism Supply Support Package to protect tourism assets and core infrastructure and to support re-opening } \\
\text { - Implement globally recognized biosecurity protocols across the value chain to enable safe travel and rebuild traveller confidence. } \\
\text { - Convene a national air access team and implement an air service development programme to connect South Africa to the world. }\end{array}$ \\
\hline $\begin{array}{l}\text { 2. Re-Ignite } \\
\text { Demand }\end{array}$ & $\begin{array}{l}\text { - Partner with accountable departments to remove barriers to travel and enable freer entry, reduced tourist crime and provide personal safety } \\
\text { and security guarantees. } \\
\text { - Catalyse domestic demand through the phases of economic re-opening with informative and inspirational messaging that encourages safe } \\
\text { tourism and domestic leisure experiences. } \\
\text { - Execute a global marketing and travel trade programme, targeted at highest potential source markets and intrepid travel consumer } \\
\text { segments, to reignite international demand }\end{array}$ \\
\hline $\begin{array}{l}\text { 3. Strengthen } \\
\text { Enabling } \\
\text { Capability }\end{array}$ & $\begin{array}{l}\text { - Launch an investment and market-entry facilitation programme to stimulate capital investment, sector transformation and product diversification. } \\
\text { - Prioritise cooperation with neighbouring destinations towards a regional value proposition and a seamless experience. } \\
\text { - Review and transform the tourism institutional architecture to deliver efficient, effective and purpose-led support for sector growth and development }\end{array}$ \\
\hline
\end{tabular}

Beyond financial aid, South African Tourism announced that it was evolving a Tourism Recovery Plan for resuscitating the emasculated tourism sector which was in danger of regressing to the point of pre-1994 when apartheid South Africa was a pariah in the international tourism economy (Rogerson and Visser, 2004). The details of this recovery plan are a work in progress. What is known already is the broad structure of responses which include three strategic thrusts and 10 strategic recommendations (Table 2). In common with the projections made in other countries the organization views recovery of the country's tourism sector will be led by a revival of domestic tourism, business travel and travel by younger rather than senior travellers (Smith, 2020c). Notably South African Tourism have not seriously acknowledged the potential of VFR travel for reactivating local tourism economies despite the fact that Backer and Ritchie (2017) demonstrate its critical role in post-disaster recovery situations. At the sub-national scale of government the City of Cape Town has set up a tourism task team to develop a local response and recovery plan. One of its planning premises for recovery planning is that "people will take shorter trips, closer to home driven by a desire to support local businesses suffering from the fallout of the crisis" (Invest Cape Town, 2020). Based on the projected trajectory of the pandemic in South Africa it is anticipated that recovery will begin only towards the end of 2020. The Minister of Tourism makes clear that a core focus for national government in recovery planning will be to reinforce its agenda for sector transformation as it views COVID-19 as "an opportunity to distribute the benefits of tourism to rural and township communities" (Kubayi-Ngubane, 2020, b:1).

Overall, it is evident that in South Africa's risk-adjusted strategy the tourism sector will be the last sector to re-open fully. The sector was assessed as a level 1/2 activity within the risk-adjusted strategy. Its opening would begin with relaxing the ban imposed on local intra-provincial travel followed by inter-provincial movements and shift to open borders allowing international travel to recommence only once South Africa has reached alert level 1. The timing and process for the re-opening of the South African tourism economy has been an issue of fierce controversy and contestation between government and the industry. Under level 4 and 5 lockdown restrictions no travel for tourism purposes was permitted. With the move to level 3 of the risk adjusted strategy on 1 June a number of minor concessions were made. Although inter-provincial travel remained restricted to those who could show a need to travel for essential purposes, limited business travel was now permissible both for land and domestic air travel creating a small market for hotels, lodges or guest houses. This said, with the threat of inspections accommodation service establishments had to demonstrate that anyone staying 
overnight was not travelling for leisure purposes. In rural areas game parks and farms were now permitted to offer self-drive excursions from visitors within the same province but visitors could not cross provincial boundaries. These initiatives did little to as sist the vast majority of tourism enterprises which pressed for further action to open up their businesses for leisure travellers. Confusion and anger was the reaction from the tourism industry following a national address by the President on 17 June that appeared to signal a relaxation for (domestic) leisure tourism to re-commence. On 26 June the Minister of Tourism indicated an error and that it was not permitted even for overnight trips of intra-provincial travel. The promulgated regulations confirmed this position and provoked strong response with threats of legal action from the leadership of the private sector Tourism Business Council of South Africa (TBCSA).

With the prospect of 1.5 million individuals facing business closure and job losses leading representatives of the formal tourism industry attacked government for its 'flip-flopping' (Naidoo, 2020a). The CEO of TBSCA resorted to Twitter to state: "This certainly defies logic. You can get a local taxi with $100 \%$ capacity but you can't stay in a hotel alone or with your family. Where is 1 ogic and consistency here? Other industries are allowed to work with less protocols". Accompanying announcements made in July of a $40 \%$ major cut in the departmental budget for tourism the poor leadership of the Minister of Tourism increasingly was criticised both for abject failure to address the concerns of the tourism industry and specifically to fight more effectively for re-opening the sector, at least for domestic leisure travel (Naidoo, 2020b). The most recent policy shift was the minor concession which was made on 30 July that interprovincial travel for leisure purposes would be permitted effective "sometime in August" (Naidoo, 2020c).

At the time of writing there was no indication of when inter-provincial leisure travel restrictions would be rescinded or when international travel to South Africa might reopen (expectations are only early 2021). A rebound of the tourism sector would be contingent obviously upon the lifting of all travel restrictions at level 1 but also dependent, to a large extent, on recovery of other sectors and of key source markets. Of particular importance for South Africa are the country's two largest international leisure markets of the United Kingdom and Germany which seemingly are further along the COVID-19 cycle. A danger is that when consumers in these markets start to resume international travel that they may not wish to travel to South Africa which might be considered a high risk destination because of its later situation in the COVID-19 cycle (Anderson, 2020). Full recovery for the tourism sector is anticipated only when the threat of the virus either has been eliminated or no longer poses a significant threat, a situation that is possible realistically when a cure or vaccine is available (cf Hall et al., 2020).

\section{Emerging impacts}

At its inception, the government's risk-adjusted strategy offered projections of the expected impact of continued lockdown across various economic sectors (The Presidency, 2020). The projections for tourism were immediate and alarming. For end-May 2020 (one month after lockdown) it was expected only 5 percent of tourism employees would be paid. In the longer-term it was anticipated that 55 percent of the pre-COVID crisis tourism workforce of South Africa would be retrenched. The most concerning expectations were that 25 percent of large firms in the tourism sector would close and as many as 75 percent of SMMEs would not survive the crisis. These projections should be viewed in light of the fact that (at least) 95 percent of all tourism enterprises in South Africa would be classed as SMMEs (Rogerson, 2005).

From early evidence of emerging impacts many of these alarming projections appear well founded. In April 2020 the national Department of Tourism partnered with the International Finance Corporation, the TBCSA and the Southern African Tourism Services Association to collaborate on a single survey measuring the impact of COVID-19 on the South African tourism industry. It is planned the survey be repeated a further three times in order to track changes over time in business sentiment (Naude, 2020). The results of the first round of this survey (undertaken 6 weeks into the pandemic) are based on a total of 1610 respondents which are drawn from across the size and spectrum of tourism enterprises including accommodation services, tour providers as well as conservancy-related and community-based enterprises (Department of Tourism et al., 2020). The key findings disclose by April 2020 a predictably depressing picture of a sector already in precipitate decline. Indeed, less than one-third of respondents believed their business would survive to take part in any recovery of the sector. Table 3 provides a summary of findings concerning business impacts.

Table 3. Business Impacts of COVID-19 pandemic on South African tourism enterprises, April 2020 (Source: Authors based on Department of Tourism et al., 2020)

\begin{tabular}{|l|l|}
\hline \multicolumn{1}{|c|}{ Indicator } & \multicolumn{1}{c|}{ Survey Findings } \\
\hline Revenue & $\begin{array}{l}83 \% \text { report decline in revenues in March 2020 by more than 50\% as compared to March 2019; for 34\% respondents } \\
\text { revenues are reduced by 100\% }\end{array}$ \\
\hline Debt service & $58 \%$ of firms unable to service debts in March 2020 \\
\hline Occupancy/Customer Use & For 85\% of firms down by 50\% or more and for 47 \% firms down by 100\%. \\
\hline Fixed Costs & $54 \%$ unable to cover fixed costs in March 2020 \\
\hline Forward bookings & As compared to March 2019 81\% firms report bookings down by at least 50\% and for 36\% respondents by $100 \%$. \\
\hline Size of firm & All sizes of firm are in decline but the worst affected are micro and small firms \\
\hline Sub-sector of firm & All are impacted but worst are those in conservancies/nature tourism \\
\hline
\end{tabular}

In terms of mitigation measures the survey revealed that $69 \%$ of businesses implemented temporary closure of operations, $58 \%$ were significantly downscaling their businesses and more than half had cancelled planned upgrades or improvements for their busine sses. The largest share of temporary closures occurred in accommodation services. In the international context Baum et al. (2020) raise questions about the precarity, vulnerablity and poor employment conditions of the tourism/hospitality workforce and suggest there is evidence of COVID-19 impacts amplifying existing inequalities. In South Africa the first insight on workforce impacts is of the differential management of workforces. The most widespread response was wage reductions; $50 \%$ of respondents reported having reduced wages for more than half of their workers and 36\% reduced wages for all staff. The furlough of staff was undertaken by $32 \%$ of respondents; redundancies were reported by nearly half $(47 \%)$ of firms. Overall, in respect of support measures for recovery, the most significant expressed needs as revealed in the survey were for financial support for cashflow and recovery, tax reductions or deferments, expert advice on business strategy, and commercial debt repayment support (Department of Tourism et al., 2020).

Geography matters as it is evident the short-term as well as the long-term consequences of COVID-19 for South African tourism will impact most severely those destinations with a local economy that is tourism-dependent and at micro-level those rural communities with livelihoods that have been imploded by the closure of tourism operations (Rogerson and Rogerson, 2020a). The controversial alcohol ban is especially devastating for the tourism economy of Western Cape province with its competitive strengths that include food and drink tourism and most especially its innovative economy of wine tourism (Ferreira and Hunter, 2017; Booyens, 2020; Ferreira, 2020). In terms of those areas which are most tourism-dependent in South Africa as indexed by the contribution of tourism spend to local gross domestic product the Western Cape has a cluster of some of the country's most vulnerable tourism spaces. For leisure-dependence the list of those 
places most at risk or vulnerable destinations includes several localities in the Western Cape including the Cape Town metropolitan area, the secondary cities of Stellenbosch, George and Paarl, and small town destinations such as Plettenberg Bay, Knysna, Swellendam and the Overstrand (Rogerson and Rogerson, 2019, 2020b, 2020c).

\section{CONCLUSION}

The COVID-19 pandemic is unlike any other disasters and crises that previously have impacted the tourism sector (Hall et al., 2020; Sigala, 2020). In common with the rest of the world the tourism industry of South Africa is experiencing the radical negative impacts of COVID-19. Indeed, the pandemic represents a crisis event that potentially is set to transform the size and complexion of South Africa's tourism sector as well as the context in which it functions. Undoubtedly, the magnitude of the pandemic will reshape extant patterns of tourism, accommodation services and commercial aviation flows for South Africa. In 2020 a hollowing out of the South African tourism industry is observed as taking place at an accelerating tempo with the most severely impacted being tourism small and micro-enterprises. This rapid response critical assessment provides an evaluation for the period March to August 2020 of government and tourism industry responses towards the pandemic in South Africa. It highlights for this lockdown period several conflicts occurring between key stakeholders and especially of the frustrations of the tourism industry about the chaotic and changing policy regulations tow ards the sector as well as the weakness of government support mechanisms. Above all, what is evidenced is national government's seeming indifference and uncaring attitude towards the crippling consequences of its interventions (or sometimes lack thereof) for the majority of the country's tourism enterprises, their tourism workforce and the livelihoods of tourism-dependent communities.

\section{REFERENCES}

Abrahams, D. (2019). Transformation of the tourism sector in South Africa: A possible growth stimulant?. GeoJournal of Tourism and Geosites, 26 (3), 821830. http://dx.doi.org/10.30892/gtg.26312-400

Anderson, A. (2020). Hotels could be your home away from home during lockdown. Asset Magazine, 81, 75-79.

Assaf, A. \& Scuderi, R. (2020). COVID-19 and the recovery of the tourism industry. Tourism Economics, 26 (5), 731-733. https://doi.org/10. $1177 \% 2 \mathrm{~F} 1354816620933712$

Backer, E., \& Ritchie, B.W. (2017). VFR travel: A viable market for tourism crisis and disaster recovery. International Journal of Tourism Research, 19, 400-411. https://doi.org/10.1002/jtr.2102

Baum, T., \& Hai, N.T.T. (2020). Hospitality, tourism, human rights and the impact of COVID-19. International Journal of Contemporary Hospitality Management, 32 (7), 2397-2407. https://doi.org/10.1108/IJCHM-03-2020-0242

Baum, T., Mooney, S.K.K., Robinson, R.N.S. \& Solnert, D. (2020). COVID-19's impact on the hospitality workforce - new crisis or amplification of the norm. International Journal of Contemporary Hospitality Managemen,. https://doi.org/10.1108/IJCHM-04-2020-0314

Bianchi, R. (2020). COVID-19 and the potential for a radical transformation of tourism? ATLAS Tourism and Leisure Review, 2020-2, 80-86.

Bogale, M., Kelkay, S. \& Mengesha, W. (2020). COVID-19 pandemic and tourism sector in Ethiopia. Horn of Africa Journal of Business and Economics (Special Issue 1, June), 1-9.

Booyens, I. (2020). Tourism innovation in the Western Cape, South Africa: evidence from wine tourism. In J.M. Rogerson \& G. Visser (eds.), New Directions in South African Tourism Geographie, Cham, Switzerland: Springer, 183-202. https://doi.org/10.1007/978-3-030-29377-2_11

Brouder, P. (2020). Reset redux: Possible evolutionary pathways towards the transformation of tourism in a COVID-19 world. Tourism Geographies, 22 (3), 484-490. https://doi.org/10.1080/14616688.2020.1760928

Brouder, P., Teoh, S., Salazar, N.B., Mostafanezhad, M., Pung, J.M., Lapointe, D., Higgins-Desbiolles, F., Haywood, M., Hall, C.M. \& Clausen, H.B. (2020). Reflections and discussions: Tourism matters in the new normal post COVID-19. Tourism Geographies, 22 (3), 735-746. https://doi.org/ $10.1080 / 14616688.2020 .1770325$

Butcher, J. (2020). Let the good times roll (as soon as possible): Why we need a post COVID convivial revolution. ATLAS Tourism and Leisure Review, 2020-2, 26-29.

Butler, R. (ed.) (2017). Tourism and Resilience. Wallingford, CABI. https://doi.org/10.3390/su10061789

Carr, A. (2020). AOTEAROA: A post-COVID nature-centric world. ATLAS Tourism and Leisure Review, 2020-2, 30-36.

Casale, D. \& Posel, D. (2020). Gender and the Early Effects of the Covid-19 Crisis in the Paid and Unpaid Economies in South Africa. Cape Town: University of Cape Town, National Income Dynamics Study (NIDS) - Coronavirus Rapid Mobile Survey Report No. 4.

Cave, J. \& Dredge, D. (2020). Regenerative tourism needs diverse economic practices. Tourism Geographies, 22 (3), 503-513. https://doi.org/10. $1080 / 14616688.2020 .1768434$

Cheer, J. (2020). Human flourishing, tourism transformation and COVID-19: a conceptual touchstone. Tourism Geographies, 22 (3), 514-524. https://doi.org/ $10.1080 / 14616688.2020 .1765016$

Corbisiero, F., \& La Rocca, R.A. (2020). Tourism on demand: A new form of urban and social demand of use after the pandemic event. TeMA: Journal of Land Use, Mobility and the Environment, (Special Issue), 91-104. https://doi.org/10.6092/1970-9870/6916

Cronje, D. (2020). Small businesses in tourism must prove they are in distress because of covid-19 to receive aid - minister. Fin24, 24 March.

Dube, K., Nhamo, G. \& Chikodzi, D. (2020). COVID-19 cripples global restaurant and hospitality industry. Current Issues in Tourism, https://doi.org/ $10.1080 / 13683500.2020 .1773416$

Ferreira, S. (2020). Wine tourism development: life cycles of wine routes, wine resorts and lifestyles in the Cape winelands. In J.M. Rogerson \& G. Visser (eds.), New Directions in South African Tourism Geographies. Cham, Switzerland: Springer, 203-226. https://doi.org/10.1007/978-3-030-29377-2_12

Ferreira, S. \& Hunter, C.A. (2017). Wine tourism development in South Africa: A geographical analysis. Tourism Geographies, 19 (5), 676-698. https://doi.org/10.1080/14616688.2017.1298152

Foo, L-P., Chin, M-Y., Tan, K-L \& Phuah, K-T (2020). The impact of COVID-19 on tourism industry in Malaysia. Current Issues in Tourism, https://doi.org/ $10.1080 / 13683500.2020 .1777951$

Gibbings, A. (2020). Cape Town hotel turned into a quarantine zone for repatriated South Africans. News24, 14 May.

Goffman, E. (2020). In the wake of COVID-19, is glocalization our sustainability future? Sustainability: Science, Practice and Policy, 16 (1), 48-52. https://doi.org/10.1080/15487733.2020.1765678

Gössling, S., Scott, D., \& Hall, C.M. (2020). Pandemics, tourism and global change: A rapid assessment of COVID-19. Journal of Sustainable Tourism, https://doi.org/10.1080/09669582.2020.1758708

Gretzel, U, Fuchs, M, Baggio, R, Hoepke, W, Laws, R, Neidhardt, J, Pesonen, J, Zanker, M., \& Xiang, Z (2020). E-tourism beyond COVID-19: A call for transformative research. Information Technology \& Tourism, 22 (2), 187-203. https://doi.org/10.1007/s40558-020-00181-3

Gursoy, D. \& Chi, C.G. (2020). Effects of COVID-19 pandemic on hospitality industry: Review of the current situation and a research agenda. Journal of Hospitality Marketing \& Management, 29 (5), 527-529. https://doi.org/10.1080/19368623.2020.1788231

Hall, C.M. (2010). Crisis events in tourism: Subjects of crisis in tourism. Current Issues in Tourism, 13 (5), 401-417. https://doi.org/10.1080/13683500.2010.491900 
Hall, C.M., Scott, D., \& Gössling, S. (2020). Pandemics, transformations and tourism: Be careful what you wish for. Tourism Geographies, 22 (3), 577-598. https://doi.org/10.1080/14616688.2020.1759131

Hamidah, I., Sriyono, \& Hudha, M.N. (2020). A bibliometric analysis of Covid-19 research using VOSviewer. Indonesian Journal of Science and Technology, 5 (2), 209-216. https://doi.org/10.17509/ijost.v5i2.24522

Higgins-Desbiolles, F. (2020a). Socialising tourism for social and ecological justice after COVID-19. Tourism Geographies, 22 (3), 610- 620. https://doi.org/ $10.1080 / 14616688.2020 .1757748$

Higgins-Desbiolles, F. (2020b). COVID-19 and tourism: Reclaiming tourism as a social force? ATLAS Tourism and Leisure Review, $2020-2,65-73$.

Huijbens, E.H. (2020). Social distancing and the promise of tourism. ATLAS Tourism and Leisure Review, 2020-2, 22-25.

Ioannides, D. \& Gyamóthi, S. (2020). The COVID-19 crisis as an opportunity for escaping the unsustainable global tourism path. Tourism Geographies, 22 (3), 624-632. https://doi.org/10.1080/14616688.2020.1763445

Jacob, B. (2020). Oscar dismisses nepotism claims over Cala quarantine B\&B owned by MEC's daughter. https://www.dispatchlive.co.za/news/2020-04-18 [Accessed 24 April, 2020).

Jain, R., Budlender, J., Zizzamia, R. \& Bassier, I. (2020). The Labour Market and Poverty Impacts of COVID-19 in South Africa. Cape Town: University of Cape Town, National Income Dynamics Study (NIDS) - Coronavirus Rapid Mobile Survey, Report 5.

Joubert, L. (2020). Covid-19 gives tourism a 'snotklap': Lessons for a climate altered future. Daily Maverick, 3 April.

Karrim, A. (2020). Covid-19: This is how lockdown levels will be assigned to districts. News24, 14 May.

Karrim, A., \& Cowan, K. (2020). Coronavirus quarantine: Hunt for new facility as talks with Free State resort collapse. News24, 6 March.

Karrim, A. \& Evans, S. (2020). Unscientific and nonsensical: Top scientist slams government lockdown strategy. News24, 16 May.

Khumalo, J. (2020). High court in favour of tourism department using race as a criterion when providing Covid-19 relief. City Press, 30 April.

Köhler, T. \& Bhorat, H. (2020). COVID-19, Social Protection and the Labour Market in South Africa: Are Social Grants Being Targeted at the Most Vulnerable? Cape Town: University of Cape Town, National Income Dynamics Study (NIDS) - Coronavirus Rapid Mobile Survey, Report 6.

Korinth, B. \& Ranasinghe, R. (2020). COVID-19 pandemic's impact on tourism in Poland in March 2020. GeoJournal of Tourism and Geosites, 31 (3), $987-990$.

Kubayi-Ngubane, M. (2020a). Covid-19 Interventions for the Tourism Sector-Mmamoloko Kubayi-Ngubane. Statement 24 March. Pretoria: Department of Tourism.

Kubayi-Ngubane, M. (2020b). COVID-19 tourism sector response measures. Bojanala (June), 1-3.

Laesser, C. (comp.) (2020). The Response of Governments vis-à-vis the Economic Ramifications of SARS-CoV-2. St Gallen, Switzerland: AIEST

Lapointe, D. (2020). Reconnecting tourism after COVID-19: The paradox of alterity in tourism areas. Tourism Geographies, 22 (3), 633-638. https://doi.org/ $10.1080 / 14616688.2020 .1762115$

Laws, E., Prideaux, B. \& Chon, K.S. (eds.) (2007). Crisis Management in Tourism. Wallingford: CABI.

Lenggogeni, S., Ritchie, B.W. \& Slaughter, L. (2019). Understanding travel risks in a developing country: a bottom-up approach. Journal of Travel \& Tourism Marketing, 36 (8), 941-955. https://doi.org/10.1080/10548408.2019.1661329

Lew, A.A., Cheer, J.M., Haywood, M., Brouder, P., \& Salazar, N.B. (2020). Visions of travel and tourism after the global COVD-19 transformation of 2020. Tourism Geographies, 22 (3), 455-466. https://doi.org/10.1080/14616688.2020.1770326

Mitchley, A. (2020). Communities reliant on Kruger National Park assisted with food parcels and water tankers. News24, 24 April.

Naidoo, S. (2020a). Domestic travel ban raises ire of tourism industry. Moneyweb, 14 July.

Naidoo, S. (2020b). R1bn budget cut for tourism department. Moneyweb, 23 July.

Naidoo, S. (2020c). Lockdown eased: 10pm curfew plus travel permitted within your own province. Moneyweb, 30 July 2020.

Naude, P. (2020). COVID-19 tourism impact survey. Available at theplanner.guru/2020/04/13/covid-19-tourism-impact-survey [Accessed 21 April 2020].

Ngqakamba, S. (2020). This is why a Limpopo resort was chosen as the quarantine site for SA's Wuhan evacuees. News24, 14 March.

Nicola, M., Alsafi, Z., Sohrabi, C., Kerwan, A., Al-Jabir, A., Iosifidis, C., Agha, M., \& Agha, R. (2020). The socio-economic implications of the COVID-19 pandemic: A review. International Journal of Surgery, 78, 185-193. http://doi.org/10.1016/j.ijsu.2020.04.018

Niewiadomski, P. (2020). COVID-19: From temporary de-globalisation to a rediscovery of tourism? Tourism Geographies, 22 (3), 651-656. https://doi.org/10. $1080 / 14616688.2020 .1757749$

Novelli, M. (2020). Travel at the time of COVID-19 - get ready for it!. ATLAS Tourism and Leisure Review, 2020-2, 13-18.

Prayag, G. (2020). Time for reset? COVID-19 and tourism resilience. Tourism Review International, https://doi.org/10.3727/154427220X15926147793595

Prideaux, B., Thompson, M. \& Pabel, A. (2020). Lessons from COVID-19 can prepare global tourism for the economic transformation needed to combat climate change. Tourism Geographies, 22 (3), 667-678. https://doi.org/10.1080/14616688.2020.1762117

Qiu, R.T.R., Park, J., Li, S \& Song, H. (2020). Social cost of tourism during the COVID-19 pandemic. Annals of Tourism Research, 84, 102994. https://doi.org/ 10.1016/j.annals.2020.102994

Ranchhod, V. \& Daniels, R.C. (2020). Labour Market Dynamics in the Time of COVID-19. Cape Town: University of Cape Town, National Income Dynamics Study (NIDS) - Coronavirus Rapid Mobile Survey, Report 9.

Richards, G. \& Morrill, W. (2020). The impact and future implications of COVID-19 in the youth travel sector. ATLAS Tourism and Leisure Review, $2020-2,57-64$.

Ritchie, B. (2009). Crisis and Disaster Management for Tourism. Clevedon: Channel View.

Ritchie, B. \& Jiang, Y. (2019). A review of research on tourism risk, crisis and disaster management: Launching the Annals of Tourism Research curated collection on tourism risk, crisis and disaster management. Annals of Tourism Research, 79, 102812. https://doi.org/10.1016/j.annals.2019.102812

Rogan, M. \& Skinner, C. (2020). The Covid-19 Crisis and the South African Informal Economy: 'Locked-out' of Livelihoods and Employmen, Cape Town: University of Cape Town, National Income Dynamics Study (NIDS) - Coronavirus Rapid Mobile Survey, Report 10.

Rogerson, C.M. (2005). Unpacking tourism SMMEs in South Africa: Structure, support needs and policy response. Development Southern Africa, 22, 623642. https://doi.org/10.1080/03768350500364224

Rogerson, C.M., \& Baum, T. (2020). COVID-19 and African tourism research agendas. Development Southern Africa, https://doi.org/10.1080/0376835X.2020.1818551

Rogerson, C.M. \& Rogerson, J.M. (2018). Africa's tourism economy: Uneven progress and challenges. In T. Binns, K. Lynch \& E. Nel (eds.), The Routledge Handbook of African Development, Abingdon: Routledge, 545-560.

Rogerson, C.M. \& Rogerson, J.M. (2019). Tourism, local economic development and inclusion: evidence from Overstrand Local Municipality, South Africa. GeoJournal of Tourism and Geosites, 25 (2), 293-308. https://dx.doi.org/10.30892/gtg.25202-360

Rogerson, C.M., \& Rogerson, J.M. (2020a). COVID-19 and tourism spaces of vulnerability in South Africa. African Journal of Hospitality, Tourism and Leisure, 9 (4), 382-401. https://doi.org/10.46222/ajhtl-19770720-26

Rogerson, C.M. \& Rogerson, J.M. (2020b). Resort development and pathways in South Africa: Hermanus 1890-1994. In J.M. Rogerson \& G. Visser (eds.), New Directions in South African Tourism Geographies. Cham, Switzerland: Springer, 15-32. https://doi.org/10.1007/978-3-030-29377-2_2

Rogerson, C.M. \& Rogerson, J.M. (2020c). Inclusive tourism and municipal assets: Evidence from the Overstrand Municipality, South Africa. Development Southern Africa https://doi.org/10.1080/0376835X.2020.1796597

Rogerson, C.M. \& Visser, G. (eds.) (2004). Tourism and Development Issues in Contemporary South Africa. Pretoria: Africa Institute of South Africa.

Romagosa, F. (2020). The Covid-19 crisis - opportunities for sustainable and proximity tourism. Tourism Geographies, 22 (3), 690-694. https://doi.org/ $10.1080 / 14616688.2020 .1763447$ 
Russo, A.P. (2020). After overtourism?: Discursive lock-ins and the future of (tourist) places. ATLAS Tourism and Leisure Review, 2020-2, 74-79.

Sigala, M. (2020). Tourism and COVID-19: Impacts and implications for advancing and resetting industry and research. Journal of Business Research, 117, 312-321. https://doi.org/10.1016/j.jbusres.2020.06.015

Smith, C. (2020a). Coronavirus: SA's luxury tourism sector 'floundering'. Fin24, 11 April.

Smith, C. (2020b). Coronavirus - SA's hotel industry 'decimated’. Fin24, 28 April.

Smith, C. (2020c). Time for domestic tourism to shine, industry hopes. Fin24, 18 April.

Smith, M.K. (2020). Well-being and tourism in a time of COVID-19. ATLAS Tourism and Leisure Review, 2020-2, 51-56.

Spaull, N., Ardington, C., Bassier, I., Bhorat, H., Bridgman, G., Brophy, T., Budlender, J., Burger, R., Burger, R., Carel, D., Casale, D., Christian, C., Daniels, R., Ingle, K., Jain, R., Kerr, A., Kohler, T., Makaluza, N., Maughna-Brown, B., Mpeta, B., Nkonki, L., Nwosu, C.O., Oyenubi, A., Patel, L., Posel, D., Ranchhod, V., Rensburg, R., Rogan, M., Rossouw, L., Skinner, C., Smith, A., van der Berg, S., van Schalkwyk, C., Wills, G., Zizzamia, R. \& Zuze, L. (2020). National Income Dynamics Study (NIDS) - Coronavirus Rapid Mobile Survey Wave 1: Overview and Findings. Cape Town: University of Cape Town, National Income Dynamics Study (NIDS) - Coronavirus Rapid Mobile Survey, Report 1.

Thomas, B., \& Laesser, C. (comp.) (2020). The Response of Tourism Businesses vis-à-vis the Economic Ramifications of SARS-CoV-2: Opening Intellectual and Real Avenues for Innovation. St Gallen, Switzerland: AIEST.

Thompson, A. (2020). Inside a hotel at Cape Town's V \& A Waterfront that's remianed open to guests during lockdown. Available at https://www. businessinsider.co.za/inside-cape towns-waterfront-lockdown hotel-2020-4 [Accessed 3 May 2020].

Tomassini, L., \& Carvagnaro, E. (2020). The novel spaces and power-geometries in tourism and hospitality after 2020 will belong to the 'local'. Tourism Geographies, 22 (3), 713-719. https://doi.org/10.1080/14616688.2020.1757747

Trade and Industry Policy Secretariat (TIPS) (2020). The Economy and the Pandemic 29 June-12 July. Pretoria: TIPS.

Turnšek, M., Gorenak, M., Brumen, B., Mekinc, J., Rangus, M. \& Štuhec, T.L. (2020). Perceived threat of COVID-19 and future travel avoidance: Results from an early convenient sample in Slovenia. Academica Turistica, 13 (1), 3-17. https://doi.org/10.26493/2335-4194.13.3-19

Yende, S.S. (2020). Quarantined South Africans head to court to demand their release. City Press, 2 May.

Zenker, S., \& Kock, F. (2020). The coronavirus pandemic - A critical discussion of a tourism research agenda. Tourism Management, 81, 104164. https:// doi.org/10.1016/j.tourman.2020.104164

*** Department of Tourism (2020). COVID-19 Tourism Relief Fund. Pretoria: Department of Tourism.

*** Department of Tourism, Tourism Business Council of South Africa and International Finance Corporation (2020). Tourism Industry Survey of South Africa: COVID-19: Impact, Mitigation and the Future. Pretoria: Department of Tourism.

*** Discovery Health (2020). COVID-19 care: Hotels open their doors for COV-19 isolation away from home. Available at https://www.discovery.co.za/ portal/corporate/covid19-hotels-open-their-doors?utm_source=Communication\&utm_medium=Email \{ Accessed 16 April 2020).

*** ILO (International Labour Organization) (2020). COVID-19 and the Tourism Sector. Geneva: ILO Sectoral Brief.

*** Invest Cape Town (2020). Guidance for Travel and Tourism Businesses Impacted by COVID-19 Crisis: Statement by the City's Mayoral Committee for Economic Opportunities and Asset Management, Alderman James Vos. Cape Town: Invest Cape Town.

*** OECD (2020). COVID-19 and Africa: Socio-economic Implications and Policy Responses. Paris: Organisation for Economic Co-operation and Development.

*** Republic of South Africa (2020a). COVID-19 block exemption for the hotel industry 2020. Government Gazette No. 65727 March

*** Republic of South Africa (2020b). Media Statement by Ministry of Tourism: COVID-19 Interventions for the Tourism Sector 24 March. Pretoria: Ministry of Tourism.

*** The Presidency (2020). Phasing Back Post-lockdown. Pretoria: The Presidency.

*** Tourism Research Network (2020). Initial TRINET responses to COVID-19 tourism. Post to TRINET-L@lists@ hawaii.edu 20 March.

*** UNCTAD (2020). COVID-19 and tourism. Geneva: UNCTAD.

*** World Bank (2018). An Incomplete Transition: Overcoming the Legacy of Exclusion in South Africa. Washington DC: World Bank Report No. 125838-ZA.
Article history:
Received: 03.06.2020
Revised: 04.07.2020
Accepted: 25.08 .2020
Available online: 15.09 .2020 